特集 $5^{*}$

肉眼的進展様式からみた胆囊癌の診断と

$$
\text { 治療につしての検討 }
$$

果察人”第 1 外科

野号俊夫黑田慧

\title{
DIAGNOSIS AND TREATMENT FOR GARCINOMA OF THE GALLBLADDER WITH SPECIAL REFERENCE TO THE MODE OF SPREAD
}

\section{Toshio NORO and Akira KURODA}

The First Department of Surgery, School of Medicine, Tokyo University

胆賈癌の診断と治療の困難性は㳂く認められ，早期発 見への努力がなされているが，胆骐の解剖学的な位置関 係や周井の血管, リンパ管の複䧱な走行により, 胆囊癌 の進展様式はさまざ屯で, 隣接臓器への漫潤, 転移も早 いので，発見時すでに切除不能の状態にあることが多 い.今回は診断ならびに外科的治療に重要な関速をるつ 胆露癌の肉眼的進展㥞式に着目して, その診断と治療に ついて検討を加えることにする。

1. 肉眼的進展㥞式による胆露癌の分類（表１）

（I）: 䏣霊限局型：㿋が胆囊に限局している.

（II）：肝浸潤型：癌が肝内に问つて直接漫潤してい る.

（III）: 胆管漫潤型 : 癌が肝外胆管内一浸溜している.

(IV)：胃腸管漫潤型：癌が主に胃, 十二指腸, 結晹な どの隣接藏器へ漫潤している.

(V) : 混合型：(II)〜（IV)の 2 つ以上を合淤する.

(VI): 腹膜播種型 : 腹獏播種を主要所見とする(以下, I , II , III , IV, V, VI型と略記する)。

\section{2. 症例の概要 (图 1)}

1960年から1975年 9 月までに東大第 1 外科で経験した 胆囊㾇は男性18例, 女性23例, 計41例で, 年令は44歳か ら79歳にわたり，平均年令は62慽之，男女とも60歳台が 最を多く，全体の50\%をしめる。

\section{3. 胆石症の合併について}

胆敕瀘41例について胆石の有無が不明であつた15例を

*符 8 回日消外総会シンポ II

脯のう癌の診断と治療一 5

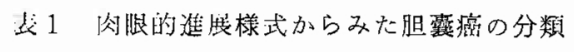
分 類

例数 \%

I 胆霊限局型

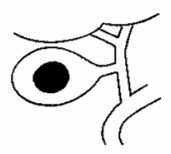

II 肝浸润型

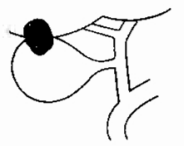

9.8

III 胆管浸润型
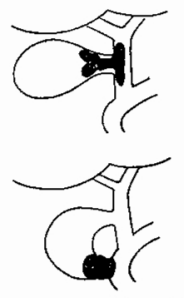

12.2

IV 霄腸管漫洞型

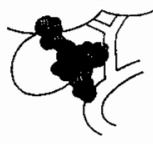

15

36.6

VI 腹膜播種型

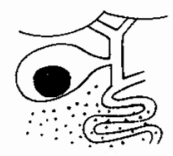

除いた残り 26 例について胆䨳結石の存否をみると, 胆石 を合併したものは17例，65.4\%で，このうち胆石の性状 が確認できた15例ではコレステリン系石対ビリルビン系 不の比は11：4であつた。一般の胆囊胆石症に拈ける両 者の比は68.5\%: $31.5 \%$ であつた。 
表 2 阻㟵癌の臨床症状（入院時）

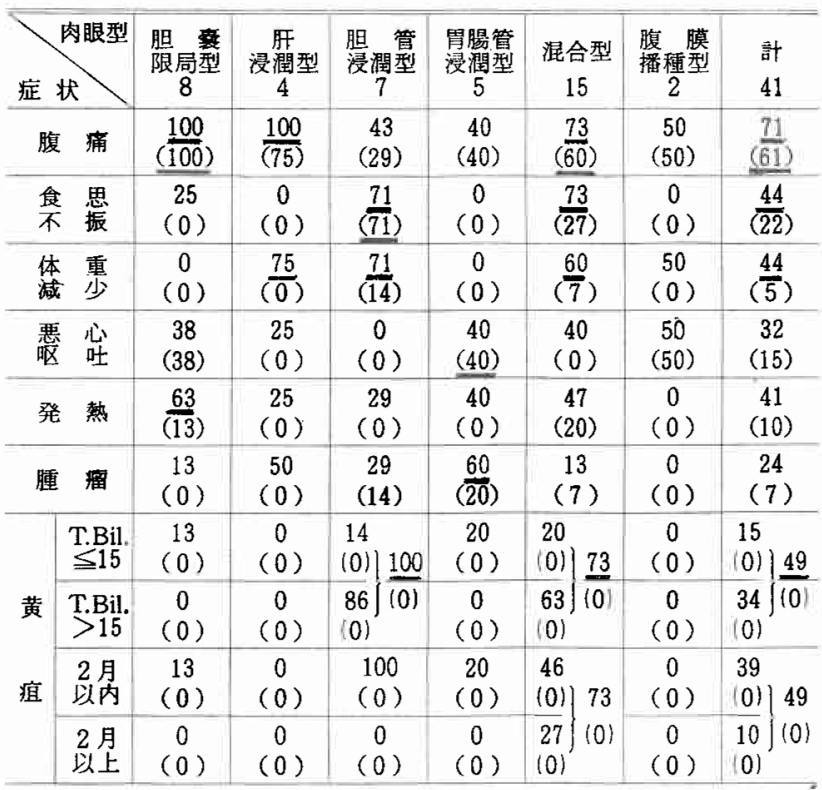

\section{（）初発怔状 数字: \%}

\section{4. 臨床的事項}

（1）病悩期間：胆道系疾患に由来すると思われる症 状発現後の期間とすると, 病悩期間は 1 月未澫から30年 以上にわたるが，60\%が6月以内であつた。切除例15例 についてもそのうら10例が 6 月以内であり，胆石合併の 有無による差も認められなかつた。

（2）臨床症状（表 2）：入院時の臨床症状として は, I 型では腹痛, 発熱, II 型では腹痛, 体重減少, II 型では黄疸, 食思不振, 体重減少, IV 型では腹部腫溜, 腹痛, 覀心呕吐, $\mathrm{V}$ 型では黄㾝, 腹痛, 食思不振, 体重 減少が比較的高率にみられた。

初発症状だけをとりあげると, 全体としては腹痛が最 も多いが，とくに正型では食思不振が腹痛よりも多く， IV型では消化管通過障害による悪心呕吐が腹痛と同頻度 であることが注目された。

黄疸はとくに型，ついでV型に多いが，血清総ビり

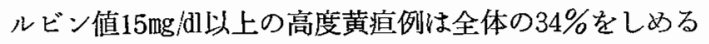
のに対し，黄疸持続期間が 2 月以上のものは全体の10\% に過ぎなかつた。

切除例15例については，黄疸は5 例にみられ，そのう ら 1 例（血清総ビリルビン值は15mg/dl以下）は I 型で， 黄疸は急性胆露资によると思われた。他の4例はいずれ
も㭬型に属する高度黄疸例で，肝外胆管への癌浸潤やリ ンパ節転移による胆管狭窄が黄㾝の原因と思われた。

（3）診断（表 3）：術前に胆翼癌と診断乙得たのは II 型 2 例， III 型 2 例, IV型 1 例, V 型 4 例, 計 9 例, $22.0 \%$ にすぎず，とくにI型では全例が胆石症または胆 哄炎之診断されて手術をらけ, 術後の病理組織学的検查 ではじめて診断が確定された。

レ線検查成績をみると, 排泄性胆縞造影では黄疽のな い21例中，胆囊陰性例は18例で，胆雴が淡く，あるいは 一部造影された造影不良例は 2 例, 胆囊の形態異常を認 めたものは 1 例で，造影陽性例 3 例はいずれるI 型の症 例であつた．経皮経肝的胆道造影，内視鏡的逆行性胆道 造影などの直接造影は正〜V型の11例に行われている が，いずれも胆䨩は造影されず，肝管または総䏣管の狭 窄, 閉塞, 陰影欠損, 拡張などが主な所見であり, 胆囊 癌を疑診するにとどまつた。低緊張性十二指腸造影は II $\sim \mathrm{V}$ 型の17例に施行され，90\%に十二指晹球部または 下行脚の王排, 壁硬化, 辺縁不整, 狭窄などの所見を得 たが，もちろん確診はでさなかつた．選択的動脈造影は II 〜 V型の12例に施行され，I型 2 例では胆輁動脈の広 狭不整 ( 1 例)，部分的濃染 ( 2 例) が， III型 4 例では 胆整動脈の広狭不整（1 例)，屈曲蛇行（2例），部分的 
図 1 胆石症之胆露瘦

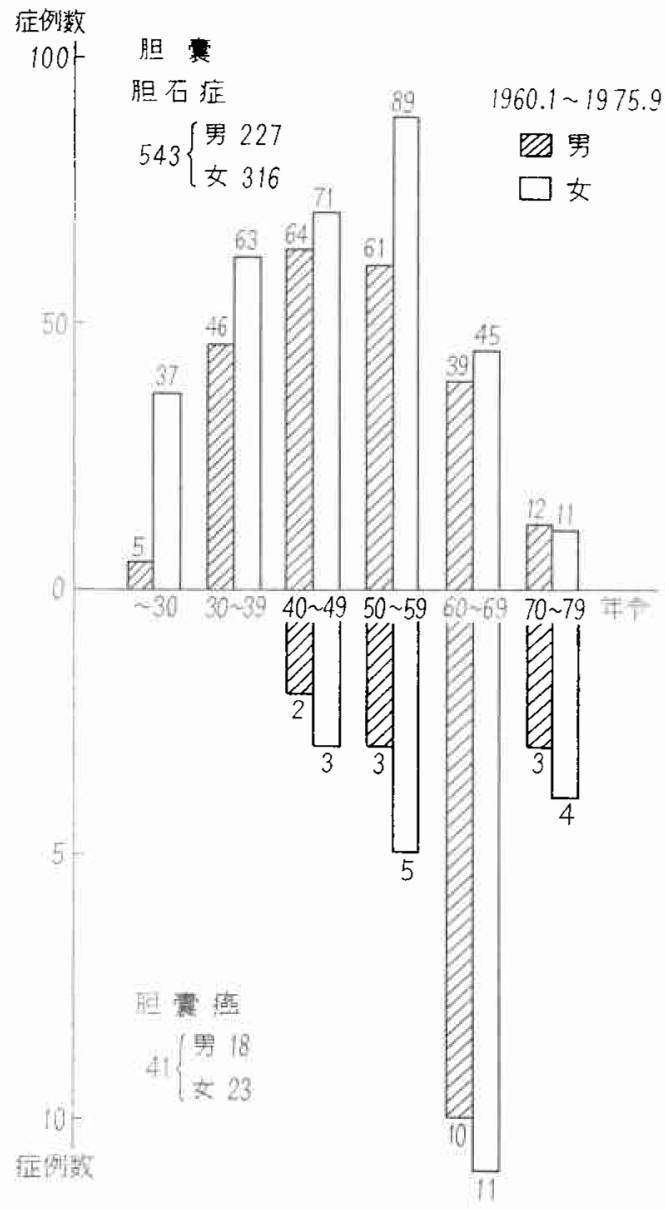

濃染（２例）または胃十二指腸動脈の圧排（ 2 例）が, IV 型 2 例では胆震動脈の広狭不整 ( 1 例), 部分的濃染 ( 1 例)，胃十二指晹動脈の圧排 ( 1 例)，血管の増生 （1 例）が，またV型 4 例では胆洼動脈の中断（2 例)， 部分的濃染 ( 1 例), 胆囊動脈領域の扗大 ( 1 例), 胃十 二指腸動脈の 王排 ( 1 例) 肝固有動脈の 浸潤 ( 1 例), 肝転移（1例）がみられた。12例中 6 例は胆襄動脈の中 断, 広狭不整, 部分的䟴染などから胆裹癌と診断し得 た。

（4）治療（表 4）：姑息的にせよ胆蛪を切除し得た のは15例で，切除率は36.6\%であつた。このうら I 型 8

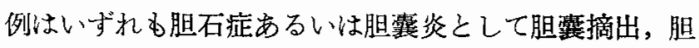

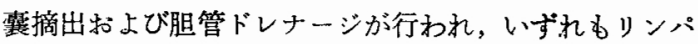
節転移はなく, 癌は胆鸾に限局しており, 治癒切除と考 えられた，II型 2 例では, 胆震を含めた肝䓃葉切除が行 われ，らち 1 例は切除肝断端に癌浸潤を認めたが，他の 1 例は治瘺切除と考学られた。型では 7 例中 4 例に胆 霊摘出，胆囊摘出および胆管ドレナージあるいは胆管切 除が行われたが，いずれる胆襄管あるいは胆管の断端に 癌漫潤を認めたＩV型では 1 例に胆噀摘出叔よび肝床楔 状切除, 胃十二指腸部分切除が行われ, 治癒切除が得ら れた。

すナわら胆䆏癌全体では治癒切除率は41例中10例, 24 .4\%であつた.

非切除例25例に対してはいずれる姑息的手術が行われ た. 黄疸軽減手術としては内外胆汁瘦が III，III, IV型の括 のおの 1 例, 3 例, 8 例, 計 12 例に行われ, 腸管通過障 害に対しては胃空晹吻合がIV, V, VI型のおのおの 3 例,

表 3 術前診断

\begin{tabular}{|c|c|c|c|c|c|c|c|}
\hline 彭断名 & $\begin{array}{l}\text { 盟 要 } \\
\text { 限局型 } \\
\text { (8) }\end{array}$ & $\begin{array}{c}\text { 䏦 } \\
\text { 浸潤型 } \\
(4)\end{array}$ & $\begin{array}{c}\text { 盟 䉕 } \\
\text { 浸㵎型 } \\
(7)\end{array}$ & $\begin{array}{l}\text { 㥜腸管 } \\
\text { 浸型型 } \\
\text { (5) }\end{array}$ & $\begin{array}{c}\text { 混合型 } \\
\text { (15) }\end{array}$ & $\begin{array}{l}\text { 腹 膜 } \\
\text { 播種型 } \\
(2)\end{array}$ & $\begin{array}{c}\text { 計 } 96 \\
(41)\end{array}$ \\
\hline 胆囊癌 & $\underline{0}$ & 2 & 2 & 1 & 4 & $\underline{0}$ & 22.0 \\
\hline 胆道滰 & & & 1 & & 5 & & 14.6 \\
\hline 胆管癌 & & & & & 1 & & 2.4 \\
\hline 胆石症 - 胆表炎 & 8 & 1 & 1 & 1 & 1 & 1 & 31.7 \\
\hline 閉塞性黄疽 & & & 3 & & 3 & & 14.6 \\
\hline $\begin{array}{l}\text { 幽門又は住 } \\
\text { 十二指腸狭窄 }\end{array}$ & & & & 2 & 1 & & 7.3 \\
\hline その他 & & 1 & & 1 & & 1 & 7.3 \\
\hline $\begin{array}{l}\text { 正診率 } \\
\text { 名 }\end{array}$ & $\begin{array}{c}0 / 8 \\
0\end{array}$ & $\begin{array}{l}2 / 4 \\
50.0\end{array}$ & $\begin{array}{l}2 / 7 \\
28.6\end{array}$ & $\begin{array}{l}1 / 5 \\
20.0\end{array}$ & $\begin{array}{l}4 / 15 \\
26.7\end{array}$ & $\begin{array}{c}0 / 2 \\
0\end{array}$ & $\begin{array}{l}9 / 41 \\
22.0\end{array}$ \\
\hline
\end{tabular}


表 4 手術術式および切除率

（ ）内治㗪切除

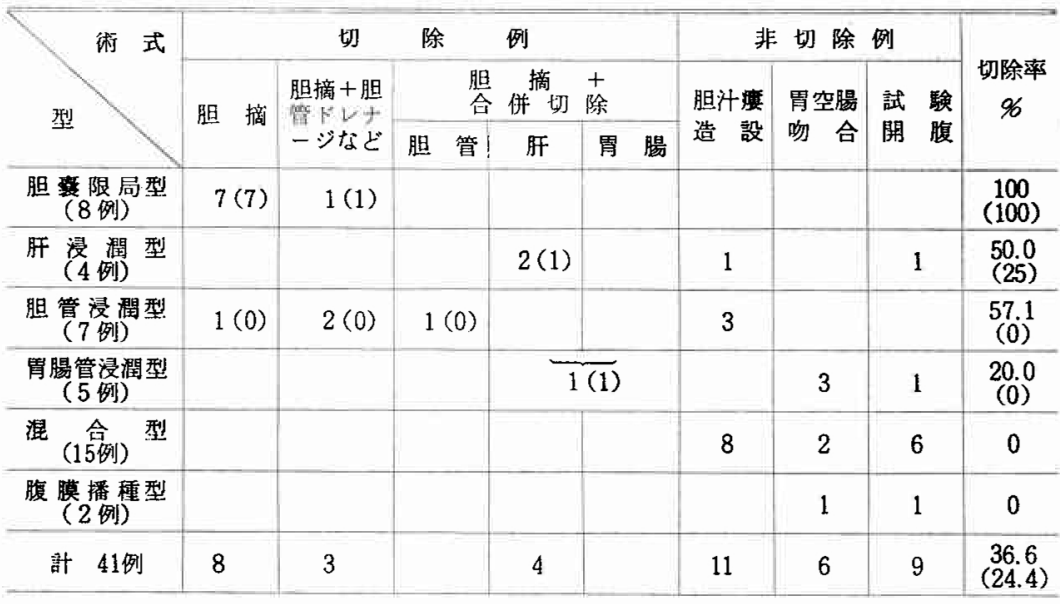

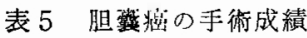

遠隔不明例 6

\begin{tabular}{|c|c|c|c|c|}
\hline & \multicolumn{2}{|r|}{ 场 除 例 (15) } & \multicolumn{2}{|r|}{ 非 切 除 例 (26) } \\
\hline & 值接死亡 & 遠 隔成 纓 & 湢接死亡 & 遠 隔 成 績 \\
\hline $\begin{array}{l}\text { 胆 䜭 } \\
\text { 限局型 }\end{array}$ & 0 & $\begin{array}{l}\text { 生存 } 4\left(\begin{array}{l}7 \text { 年11月, } 4 \text { 年 } 9 \text { 月 } \\
1 \text { 年10月月, } 9 \text { 月 }\end{array}\right) \\
\text { 死亡 } 4\left(\begin{array}{l}2 \text { 年11月, } \\
6 \text { 月, } 3 \text { 年10月 }\end{array}\right)\end{array}$ & - & - \\
\hline 浸閪型 4 & 2 & - & 0 & 死亡 2 ( 2 月, 3 月 $)$ \\
\hline 盟管 7 & 11 & 死亡 $3\left(\begin{array}{l}1 \\
4 \text { 年 } 10 \text { 月， } 5 \text { 月 }\end{array}\right)$ & 1 & 死亡 1 （2月） \\
\hline $\begin{array}{l}\text { 胃腸管 } \\
\text { 管潤型 }\end{array}$ & 0 & 死亡 1 （15年） & 1 & 死亡 2 (3月， 3 月） \\
\hline 混合型 15 & - & - & 3 & 死亡 $8\left(\begin{array}{l}2 \text { 月, } 2 \text { 月, } 2 \text { 月, } \\
2 \text { 冐, } 5 \text { 月月, } 6 \text { 月, } \\
\text { 月, }\end{array}\right)$ \\
\hline $\begin{array}{l}\text { 腹 膜 } \\
\text { 播種型 } 2\end{array}$ & - & - & 1 & 死亡 1 （2月） \\
\hline
\end{tabular}

2 例， 1 例，計 6 例に行われた。試験開腹にとどまつた あのは II, IV, VI型の各 1 例, V型の 6 例, 計 9 例であつ た。

（5）成績（表 5）：手術による直接死亡は II 型2 例, II 型 2 例, $\mathrm{IV}$ 型 1 例, V 型 3 例, VI型 1 例, 計 9 例，22.0\%で，その原因之なつた合併症のうちわけは， 腹腚内出血 2 例, ショック 2 例, 肺合併症 2 例, 横隔膜 下膿瘍 2 例, 癌性胸膜炎 2 例などであつた.

直接死亡を除く切除例の遠隔成績をみると，I 型では 4 例が括の括の 7 年11月， 4 年 9 月， 1 年10月， 9 月生 存中であり，他の 4 例は 3 月〜 2 年11月，平均 1 年 4 月 で再発死亡している。 III 型の 3 例はおの括の 4 月， 5
月, 1 年10月, 平均10月で再発死亡し, $\mathrm{N}$ 型の 1 例は 15 年間生存した。

非切除例では直接死亡 6 例を除く20例中, 追跡し得た 14例では, 最長 8 月, 平均 3.4月で死亡した.

5 年生存例 2 例について述べると，まずI 型の 7 年11 月生存中の例は 46 歳男性で, 30 数年間に上腹部疝痛発作 の既住が数回あり, 昭和 42 年 9 月同様の症状と発熱, 軽 度の黄疸, 胆整造影陰性, 右上腹部圧痛などのために胆 霝炎として開腹手術をうけ，切除胆雍底部に $2 \times 2 \mathrm{~cm}$ 結節型の隆起が認められ，組織診断で癌と診断されたも のである.他の 1 例は 50 歳の女性で，20数年間に数回の 上腹部疝痛発作があり, 昭和 24 年右上腹部に手挙大の腫 
瘤を発見され，手術のために来院した．上記腫瘤と中等 度の貧血以外飞とくに所見はなく，開腹すると，胆䨳を 中心に腫瘤を形成し, その一部は朋, 胃幽門部, 大網に 瘾着浸㵎していた。 そこで肝床楔状切除㧍よび胃十二指 腸, 大網をふくめた胆麗部腫瘤摘出術が行われ，組織診 断で䏣囊癌と判明したが，その後15年生存したものであ る.

\section{5. 病理学的事項}

組織像をみると, 不明例 3 例を除き, 38例中37例， 97.4\%は腺癌で, 腺徧平上皮癌は 1 例にすぎなかつた。

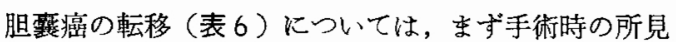
をみると, 局所りンパ節転移は切除例では开型の 1 例に 認めたのみであるのに対し, 非切除例では II 型 2 例, III

表 6 手術時就よび剖検時所見

\begin{tabular}{|c|c|c|c|c|c|}
\hline & $\begin{array}{l}\text { 手術時 } \\
(40 \text { 例) }\end{array}$ & 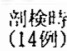 & & & \\
\hline 朋粉格 & $33 \%$ & $86 \%$ & & & \\
\hline 朋润接淁润 & $30 \%$ & $100 \%$ & & & \\
\hline 1)ンパ節軽移 & $48 \%$ & $86 \%$ & & & \\
\hline 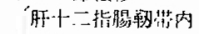 & $78 \%$ & $83 \%$ & & & \\
\hline 膵後期 & $50 \%$ & $58 \%$ & & & \\
\hline 㥹朋動脈幹 & $50 \%$ & $25 \%$ & & & \\
\hline 晹䦌膜根部 & $22 \%$ & $14 \%$ & & & \\
\hline 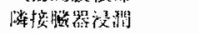 & $33 \%$ & $86 \%$ & & & \\
\hline 脽膜彩研 & $5 \%$ & $57 \%$ & & & \\
\hline 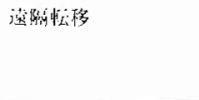 & $17 \%$ & 5796 & 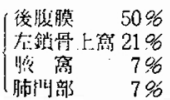 & 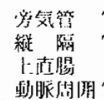 & $\begin{array}{l}7 \% \\
7 \% \\
7 \%\end{array}$ \\
\hline
\end{tabular}

型 2 例, IV型 2 例, V 型11例, V型 1 例, 計18例飞悥め られた。転移のみられたリンパ節の部位別頻度は肝十二 指腸勒带内 $78 \%$ ，膵後部，総肝動脈幹に打のおの $50 \%$ で あつた、肝転移は33\%，肝直接浸潤は30\%に認められ た。

一方，胆囊癌14例の剖検所見をみると，局所および遠 隔リンパ節転移は86\%に認められ，このうち局所リンパ 節転移は肝十二指腸勒带内 $83 \%$ ，膵後部 $58 \%$ ，総肝動脈 幹 $25 \%$ であつた。肝直接浸潤は $100 \%$, 肝転移，隣接臓 器浸潤は沶のおの86\%に認められた。

阳翼限局型 8 例の切除標本で癌の大きさと深達度の関

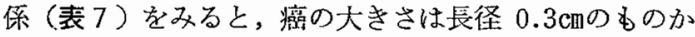
ら胆繁企体におよぶまのであるが，深達度は固有筋層采 でにとぞまるものと，漿膜下に及ぶものとがあつた。

癌の浸潤が矨層までにとどまつていた 3 例はいずれす 7 年11月，4年 9 月， 1 年10月生存中であるのに刘し， 癌のひろがりは小さくても癌浸潤が筋層をこえて漿膜下 にまで達していた 5 例では，9月生存中の1例を除き， 他はすべて最長 2 年11月までに再発死亡しているのが注
表 7 胆䨞限局型の病理組織と予後

\begin{tabular}{|c|c|c|c|c|c|}
\hline NNo. 年年 & $\begin{array}{c}\text { 占积部位 } \\
\text { 大きさ }\end{array}$ & 深道 & 闪眠型 & 組儎型 & 予後 \\
\hline 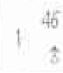 & 4 & & 结咕盟 & $\begin{array}{c}\text { 乳頭腺管 } \\
\text { 腺癌 }\end{array}$ & $\begin{array}{l}7 \text { 年11月 } \\
\text { 生存中 }\end{array}$ \\
\hline 2 . & & & & " & $\begin{array}{l}4 \text { 年9月 } \\
\text { 生存中 }\end{array}$ \\
\hline 3) & 9 & & 乳頭型 & $\begin{array}{l}\text { 乳頭 } \\
\text { 腺 }\end{array}$ & $\begin{array}{l}1 \text { 年10月 } \\
\text { 生存中 }\end{array}$ \\
\hline $4 \frac{67}{9}$ & 美 & & 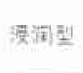 & 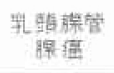 & $\begin{array}{c}\text { 9月 } \\
\text { 生存中 }\end{array}$ \\
\hline 5.71 & & & 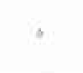 & 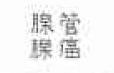 & $\begin{array}{l}2 \text { 年11月 } \\
\text { 再発死亡 }\end{array}$ \\
\hline $6 \begin{array}{l}75 \\
9\end{array}$ & 15 & & 乳頭型 & $\begin{array}{c}\text { 乳頍腺管 } \\
\text { 腺癌 }\end{array}$ & $\begin{array}{l}\text { 1年10月 } \\
\text { 再発死亡 }\end{array}$ \\
\hline 7 & $\begin{array}{l}3 \\
\frac{3}{3} \\
\text { In }\end{array}$ & & 結節型 & $\begin{array}{l}\text { 腺扁平 } \\
\text { 上皮癌 }\end{array}$ & $\begin{array}{c}\text { 6月 } \\
\text { 再発死亡 }\end{array}$ \\
\hline 8 . & $\begin{array}{l}3 \\
3 \\
25\end{array}$ & & A & $\begin{array}{l}\text { 腺管 } \\
\text { 腺痹 }\end{array}$ & $\begin{array}{c}\text { 3月 } \\
\text { 再発死亡 }\end{array}$ \\
\hline
\end{tabular}

目された。

\section{6. 考 案}

胆整癌の発生は年令とともに増加し，男女とも60歳台 に最も多く，胆石症の年令分布のピークよりも約 10 歳高 令側にかたよつていること，胆慗癌においては胆石の合 併が高頻度にみられ，しかも胆石の性状はコレステリン 系石が圧倒的に多いことなど，教室例も内外の多数 ${ }^{1) \text { 4) }}$ の報告とほ涪同様の傾向を示している。

病悩期間については胆石症に比し一般に 短いという 報告 ${ }^{5)}{ }^{6)}$ が多いが，詳細に調べると，胆道系由来の長期 にわたる症状が高頻度にみられることも注目されてい る ${ }^{4) 6)}$. 教室例では病悩期間は60\%が 6 月以内で，胆石 合併の有無による差は認められなからたが，進展様式別 にみると, 四型では平均 2.5月と他の型に比し短い傾向 がみられた。これは他の型に比較して早期に黄疸が出現 しやすいことによると考えられた。

症状については，腹痛が最も多く90〜70\% ${ }^{8) ~ 10) て ゙ ， ~}$ ついで体重減少が50 30\% ${ }^{6) 4}$ ，黄疸が $40 \sim 30 \%{ }^{8) 11}$ ，食 思不振が50〜25\% ${ }^{4) 6)}$ と報告されている。

教室例では胆踛癌全体としてみると，腹痛が最も多 く, ついで黄疸, 食思不振, 体重減少, 発熱, 悪心呕吐 などとなるが，進展様式別にみると，腹痛はＩ，II 型で \100\%，黄疸は型で $100 \% ， \mathrm{~V}$ 型で73\%，食思不振は 
III、V型で括のおの $71 \%, 73 \%$, 体重減少は II , III, V型 で拈の打の $75 \%, 71 \%, 60 \%$, 腹部腫瘤は II, IV 型でお のおの50\%，60\%と他の型に比して高率に出現し，肉眼 的進展樣式により症状が異なる傾向がみられたことが注 目される。

初発症状海ると, I , II 型では腹痛が注涪全例にみ られ，而型では食思不振が腹痛より多く、 $\mathrm{N}$ 型では悪心呕 吐が腹痛と同じ頻度にみられ，やはり進展様式によつて 異なる傾向がみられる。このような症状の差異関して は Holmes ${ }^{91}$ らも胆囊癌を 3 群に分けて報告している。

胆囊癌の診断は一般にき初めて困難とされ, 術前診断 名は胆石症, 胆囊炎, 肝外胆道癌, 膵頭部癌, 総胆管胆 石，胃癌などさまざまにわたり，術前診断率は10\%以下 の報告 ${ }^{824)}$ が大部分で，良くても20\% 30\%台の診断率 が報告 ${ }^{13)}{ }^{14)}$ されているに過ぎない。

教室例の診断率は22.0\%であつたが，II 型が50\%と最

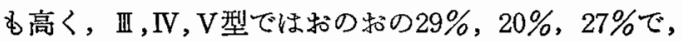
I 型は全例胆石症をたは胆慗炎とされた。

診断に用いられる各種検查法のうち，排泄性胆道造影

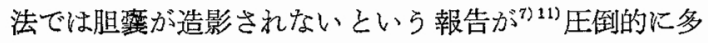
く, 教室例でも黄㡺のない21例中, 胆囊造影陽性例は造 影不良例む含めて 3 例にすぎず，I型の例でも大部分陰 性であつた.これは胆囊壁の癌浸潤あるいは随伴する胆 哥炎のために胆囊の機能が廃絶したり, 胆婯管が閉塞し たりしていることによると考它られる。しかし早期の胆 襄癌では, 胆囊内汇可動性のない陰影欠損像を認めると

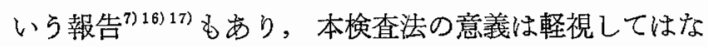
らないと思われる。

経皮経肝的胆道造影，内視鏡的逆行性胆道造影などに よる直接胆道造影法では, 胆囊造影陰珄所見に加えて, 総胆管, 総肝管さらには肝内胆管の狭窄, 閉塞, 陰影欠 損などの所見が得られることが多く, 胆慗癌の確診は困 難でも，その存在診断や胆管浸潤の有無を知るには有用 で, とくに早期の澏の診断には不可欠の検查法と考えら れる。低緊張性十二指腸造影では，十二指腸球部または 下行脚に圧排像などの所見が施行例の $90 \%$ にみられ, 進 行癌では本法の存在診断的意義は少なくなく，とくに胃 腸管漫潤の有無, 程度の䛦断には有用之思われる。

選択的動脈造影法は現段階では最も有力な診断法で， 佐藤 ${ }^{14}$ は本法で胆箩癌の術前診断率が著しく向上したと 報告しているが，教室例では，II，II，V型など施行例の 50\%に診断を下し得た。をた本法により胆黹癌の進展様 式もある程度推測し得る。
胆裂癌（とくに早期の微小な病変）の診断はこれら検 查法のすべてを駆使しても難かしく, 現病歷, 症状を含 めた綜合的な診断法の確立が望をれる。それとともに胆 囊造影陰性例に対する経皮的胆襄直接穿刺造影法なぞる 癌の人工的播種の绝険性を十分認識した上で, 今後検討 されてょい方法と思われる。

胆垡癌の病型ないし進展栐式については, 穴沢 ${ }^{18)}$, 牧 野 ${ }^{199}$ は胆囊限局型, 胆管浸潤型, 隣接藏器浸潤型, 腹膜 播偅型の 4 型をあげ, Fahim ら ${ }^{20)}$ は進展様式として, 旰転移, リンパ節転䔟, 血行性転移, 周囲臓器への連続 浸潤, 胆管内進展, 神経性進展の 6 型と分け, 肝転移は 直接浸潤の型をとつて，限局性であることが多く，多発 性の転移によりりンパの正常な流れが阻害されて肝への リンパの逆流が起る場合か, あるいは, 門脈とほとんど 交通がないといら胆萿静脈の性格から, 末期後腹膜静 脈への癌浸潤を介しておこる血行性転移の場合であると している. 教室例のII型 4 例中 2 例では肝床の近傍に限 局した浸潤を認めた以外には転移を認めず，他の 2 例で は打の打の左葉，右葉に 1 個の転移を認めている。肝に 多発性の転移を認めたものは, 林, VI型各 1 例, IV 型 2 例, V型 4 例, 計 8 例で, そのうち 5 例では両葉に, 残 る 3 例では右葉のみに認められた． III型の癌では Fahim $ら^{20)}$ も述べている如く，胆管内整に沿つて進展する様式 があるように思われる。この型のものは肉眼所見以上に 広く胆管内を浸潤している場合があり，教室に打ける切 除例 4 例はいずれも切除断端飞癌浸潤を認めている. $\mathrm{IV}$ 型のごとく胃, 十二指腸, 結腸などの隣接缄器へ直接 浸潤する例がかなり多いのは胆襄癌の特徵の 1 つとい兄 る.この型の場合でむ隣接臟器の合併切除を行党ば根治 の可能性が残されていることが教室の長期生存例によつ て示唆される.V型は高度の進行癌でもはや切除の適応

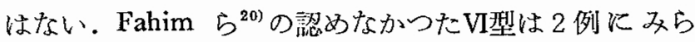
机た。

これら胆䇥癌の進展様式は Peifferscheid ${ }^{211}$ も指摘して いるよらに, 癌の発生部位によつてる買なると思われ， 嵒が䏣装頝部に登生すれば胆管に進展する頻度が高まる らし, 肝床に近い部に発生した癌ならば, 肝への直接浸 潤が多くなるであるらと推定される。胆䨢癌にみられる 肝転移、リソパ節転の部位とその頻度とついて手術時特 よび剖検時の所見を検討したが，諸家の報告22) 23) 38) とほ 媇同様であつた。

病理組織学的所見で㤬, 腺癌が圧倒的に多く, 100 $60 \%$ と報告 ${ }^{1124) 25)}$ されており, 他に腺棘細胞癌, 扁平上 
皮癌，類上皮癌，未分化癌などがあるが，教室例では腺 扁平上皮癌の 1 例以外は全て腺癌であつた。

ここで比較的早期の癌である I 型の病理組織所見と予 後との関係をみると, 7 年, 4 年生存中の 2 例は Hanser の肉眼分類では結節型に属し，組織型は乳頭腺管腺癌で あり, 癌の深達度はいずれも筋層までにとどまつてい る.癌の深達度と予後については, Appleman ら ${ }^{25)}$ は21 例の長期生存例中10例では癌が漿膜下までおよんでいた が隣接臓器には波及していなかつたとのべ，黑柳 ${ }^{26)}$ は筋 層までの浸㵎にとどまる例ではリンパ節転移を認めず， 予後は良好であるとのべている，教室例では漿膜下にま で癌浸潤のおよんでいる例は，その大小，肉眠型，組織 型の如何にかかわりなく，短期生存中の 1 例を除き全例 再発死亡している.胆霊癌の予後が一般に癌の大きさよ りも深達度により左右され，大きさと深達度との間汇は 一定の関係を認めないといら報告は他 ${ }^{27) 28399}$ 亿もある.

胆露癌の切除率は，姑息的切除も含めると $24^{11} \sim 73^{293}$ $\%$, 治㾉切除率は $9^{24)} \sim 32^{300} \%$ と報告されている. 教室

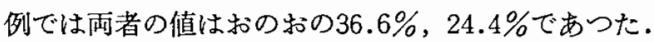

胆栾癌の手術術式と乙てはまず単純胆囊摘出術があげ られるが，この術式では胆整限局型でも 5 年生存率は $0^{32)} \sim 32^{31)} \%$ と低率であり, 教室例でも 8 例中 4 例は 2 年11月以内に再発死亡している。これらの成績はこの術 式が胆囊限局型の癌の場合でも不十分な術式であること を示している.このことから肝床の部分切除が提唱さ れ，行われてきたが，この術式については, Adson 5 $5^{33)}$ の如く好成續を報告するすのもある一方，全く無意味 であると主張する報告 ${ }^{29}$ もある。この術式の評価はま だ定つていないが，早期の胆囊癌に適応があるとする 見解 ${ }^{142533)}$ が少なくない，さらに大規模な拡大根治術 式としては肝右葉切除があるが，この術式にも替否両

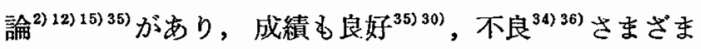
な報告が行われている.教室例ではI型の 2 例に右葉切 除が行われ，1 例は切除断端に癌浸潤を認め, 結果的に は姑息切除となつたが，他の1例は（不幸にも術後死亡 したが), 断端浸潤, リンバ節転移, 他臟器への浸潤い ずれも認めず，右葉切除の根治手術としての可能性を示 しているとい方る、しかしながら右葉切除は侵襲が大き

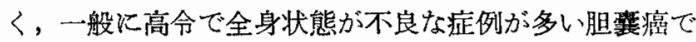
は，本術式の手術適応は籗格に決定すべきであるう。

胆囊癌の遠隔成績については 5 年生存率は $0^{24) 37)}$ $9.7 \%^{97}$ と報告されて招り，治癒切除例の生存率で名高 々 $30 \%{ }^{14)}$ と不良である. 教室例では全症例の 5 年生存率

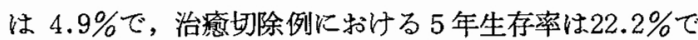
ある。

$$
\text { まとめ }
$$

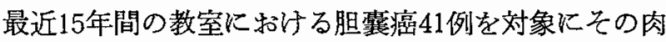
眼的進展様式からみた診断および治療について検討し た。胆埨癌においては肉眼的進展様式によりやや症状を 異にし，各種検査法の診断率にも差がみられるが，また 肉眼的進展様式は癌漫潤の方向之程度を推定する参考に もなるので，診断上，外科的治療上有用であると考兄ら れる，胆囊癌の根治はきわめて困難であるが，胆製限局 型で癌の深達度が固有節層までにとどまる例で怯胆曧摘 出のみでも根治の可能性はある。しかしこの場合でも少 なくとも局所リンパ節廓清は十分になされるべきであ る. 胆偊限局型で漿膜下浸潤を伴う例, 肝浸潤型, 胆管 浸潤型，胃腸管浸潤型では局所リンパ節の遊清とともに 他蔵器合併切除が必要であり,それによつて根治が期待 できる場合がある．胆襄癌の早期発見への努力が重要て あることは勿論でが，現状に批いてる胆石症手術に際し ては胆露癌合併の可能性を配虑することが治療成績向上 につながると考光る。

（石川浩一教授のご校閲を感謝する。）

\section{文献}

1) 佐藤寿雄 : 外科治療, $23: 645$, 昭 45 .

2) 亀田治男, 他 : 日本臨床, $30: 1966$, 昭 42 .

3) E.G. Ohlsson et al.: Acta. Chir. Scand., 140: $475,1974$.

4) J.B. Klein et al.: Arch. Surg., 104: 769, 1974.

5) 槙 哲夫, 他 : 日本臨床, $24: 1068$, 昭 36 .

6) M.J. Solan et al.: Brit. J. Surg., 58: 593, 1971.

7) M.A. Hardy et al.: Amer. J. Surg., 102: 800, 1970.

8) K.W. Warren et al.: S.G.O., 126: 1036, 1968.

9) S.L. Holmes et al.: S.G.O., 133: 561, 1971.

10) G.O. Strauch: Surgery, 47: 368, 1960.

11) E.C. Andrews et al.: South. Med. J., 62: 573, 1969.

12) L.B. Pemberton et al.: Amer. J. Surg., 122: $381,1971$.

13) F. Nakayama et al.: Jap. J. Surg. 4: 96, 1974.

14）佐藤寿雄，他：日本医事新報，2671，16，昭50.

15）菅原克彦，他：外科, 33:1239, 1971.

16) K. Rabinov: Gastroenterol., 50: 808, 1966.

17）大藤正雄，他：日消誌，66：146，1969.

18）穴沢雄作：治療, 55, 1327, 1973.

19）牧野惟義：日本医事新報，2455：43，昭 46 .

20) R.B. Fahin et al.: Ann. Surg., 156: 114, 1962. 
21) Reifferscheid, M.: Lang. Arch. Klin. Chir., 261: 513, 1949.

22) Burdette, W.J.: Ann. Surg., 145: 832, 1957.

23) Fahim, R.B. et al.: Arch. Surg., 86: 176, 1963.

24) Keill, R.H. et al.: Amer. J. Surg., 125: 726, 1973.

25) Appleman, R.M. et al.: S.G.O., 117: 459, 1963.

26）黑柳弥寿雄,他：日本医事新報, $2582 ： 15$, 昭48.

27) 榊原 宣, 他: 外科治療, $30: 137,1974$.

28）篠田正昭, 他：京府医大誌, $80 ： 445,1971$.

29) 中瀨 明, 他: 外科治療, $30: 70,1974$.

30) Glenn, F. et al.: S.G.O., 99: 529, 1954.
31) Gerst, P.H.: Ann. Surg., 153: 369, 9161.

32) Ram, M.D.: S.G.O., 132: 1044, 1971.

33) Adson, M.A.: Surg. Clin. North. Amer., 53: $1203,1973$.

34) Pack, G.T. et al.: Ann. Surg., 142: 6, 1955.

35) Blasfield, R.D.: Ann. Surg., 153: 563, 1961.

36) Warren, K.W. et al.: Lahey Clin. Found. Boll, 16: 241, 1967.

37) Johnson, I.W. et al.: Amer. Surgeon., 40: 456, 1974.

38) Ackerman, C.A. et al: Cancer, C.V. Mosby Co., St. Louis 1962.

39）黒田 慧, 他：日外会誌, $76: 1135,1975$. 